\title{
Improving Society Through the Decisions of the Human Rights Committee on the Protection of Human Dignity
}

\author{
JOVANOVIĆ Ljiljana ${ }^{36}$
}

\begin{abstract}
The idea of protecting the dignity of human beings as individuals and members of the human species, the recognition of human rights is one of the most important achievements of modern social systems. It is result of deep aspirations of humanization of moral and physical integrity of a person. Inherent dignity rests on the peculiarities of human nature and is its existential value. Legal protection of the dignity is continuously improving its mechanisms and instruments in an international environment, with the aim of respecting the individuality of individuals. The Human Rights Committee (HRC) force the provisions of the International Convent of Civil and Political Rights for the protection of human rights and fundamental freedoms and its decisions form a separate human rights protection system. The research particularly included the researching the HRC recommendations that invoke the protection of human dignity in their statements of reasons when establishing a violation of a certain human right and by analysing their contents I found the areas guaranteed by the ICCPRwhich are most prone to violation of human dignity. Analysing the HRC case law, one becomes aware of the evolving humanisation of access to protection of human dignity. Harmonization of legal systems of the state parties to the Convention, creates strong support of human rights and improving the sociological structure of modern social systems.
\end{abstract}

Keywords: dignity, human rights, Human Rights Committee

JEL: I00

UDK: 341.231.14

COBISS.SR-ID 253517836

\section{Introduction}

The Human Rights Committee (HRC) force the provisions of the International Convent of Civil and Political Rights (ICCPR) for the protection of human rights and fundamental freedoms and its decisions form a separate human rights protection system. Under article 28 of the Covenant, Committee members must be "persons of high moral character and recognized competence in the field of human rights" with "consideration given to the usefulness of the participation of some persons having legal experience" (hhtps://reaties.un.org/publication /volume999/). Starting from the assumption that the dignity of each individual must be respected in all life circumstances and that the HRC with its objective and just assessment of facts and evidence in interpreting the ICCPR provisions helps change legal systems of state parties, I will endeavour to objectively assess the influence of the HRC recommendations on improving the legal systems of state parties to protect human dignity, as an ethical value and the

36 Department for academical and general affairs at the University of Montenegro, Montenegro, jovanovicljiljana78@gmail.com 
source of human rights. At the same time, I will endeavour to determine whether the conceptualisation of the term of dignity extends the structure of human rights in legal and sociological elements.

The main goal of the research is to determine the impact of the HRC case law and its recommendations is seen in the individualisation and conceptualisation of the notion of dignity thus creating new levels of protection for human dignity by individualising specific circumstances. In the first part of the paper, the term dignity will be defined through relevant theoretical presentations, and then in the second part will be continue with a look at the evolution of human rights through theoretical considerations that shaped the social awareness of understanding the essence of human rights. The third part section will present the research conducted with its findings and the discussion thereof, and finally end with conclusions.

The protection of human rights was first set globally following World War Two with the establishment of the United Nations. The United Nations Charter was adopted on 26 June 1945 with the aim: "To reaffirm faith in fundamental human rights, in the dignity and worth of the human person, in the equal rights of men and women and of nations large and small" (http://www.un.org/en/charter-united-nations/).The Charter is the first treaty in the international law that established the internationalisation of human rights. Further evolution of contemporary international human rights protection was seen through the adoption of the 1948 Universal Declaration of Human Rights, that compiled all human rights provisions available at the time and gave a boost to further development of human rights. Article 1 of the Declaration states that: "All human beings are born free and equal in dignity and rights. They are endowed with reason and conscience and should act towards one another in a spirit of brotherhood" (http: www.un/org/en/universal-declaration-human - rights). Recognition of dignity and its protection in legal regulation of contemporary states is a reflection of the degree of democratisation of each society. The Declaration aim of protecting dignity and human rights is pursued by invoking international instruments ratified by state parties, which implies, first and foremost, substantial changes in their respective legal and judicial frameworks, aspiring to align their legislation and practice with the commitments made by ratifying those international instruments. The HRC is implementing the ICCPR provisions, thus developing its case law in human rights protection.

In the present research, I will use the historical method, the induction and deduction methods, as well as the sociological method.

\section{Dignity}

Dignity has always been the subject of interest among philosophers, lawyers, sociologists, members of different religious denominations, and the like. Dignity is a term applied to highlight specific features of human beings, noble and elevated values, embraced as such in the system of ethical norms. Through out history, it was interpreted differently by different religions, cultures and civilisations in different parts of the world. In Christina tradition, the oldest grounds for human dignity may be found in the biblical revelation Imago dei, or in God's image, and has the power over nature given the existence of human intellect. According to Lutz, this view was reiterated by the French philosopher Jacques Maritain who believed that: "The deepest layer of the human person's dignity consists in its property of resembling God" (Lutz, 1995). In early days of human community's development, dignity was mostly linked with the relation of the state towards specific societal groups, where higher classes were privileged and shown more respect compared to lower classes. The ancient thinkers endeavoured to align the ethical and moral principles of their time with the state and political agendas. For Ancient Greeks, as well as for Romans, the world is hierarchical in its essence, with privileges for men from higher classes deserving dignity due to their noble descent, wealth and social status.

The rest were regarded as lower humans - barbarians - who had no value nor deserved any respect for their dignity. In the early views of ancient Greek philosophers, based on laws of nature, we encounter the study of a human being as a spiritual and moral being. For Heraclitus, 
ethical values of a man are particularly valuable, since "a man's character is his daemon" (Heraklitus, 2006), and the life of a man is moral and happy if subordinated to general law.

In Ancient Rome, dignity was not defined as an inherent feature of human beings, rather as a social status that each individual attains within the society. The common feature between the views in the Ancient Rome and Greek, and the contemporary understanding of dignity is in their shared core, i.e. the sense of value requiring respect. Through the dark period of the Middle Ages, Thomas Aquinas considered the nature of human existence and believed that the "the notion of species pertains to human nature according to the existence human nature has in the intellect." (Aquinas, 2003). He sees reason as the essential and universal feature of all human beings which ensures their uniqueness and peculiarity in nature. After the Middle Ages, the era of Renaissance and Enlightenment brought along the ideas that gave each individual the right to freedom, happiness and progress. Awareness of human rights has been formed on theories of Locke, Rousseau, Kant.

John Locke, developed the idea of natural law implying life, liberty and property. He believed that state should support the pursuit of the natural rights of men. Tom Bingham reminded that "fundamental truth propounded by the great English philosopher John Locke in 1960 that "Wherever law ends, tyranny begins" (Bingham, 2011). In this period, Jean-Jacque Rousseau promoted the liberal ideas of dignity and equality among individuals and the individual right to liberty. For Kant, dignity is above all other values, since individual dignity is priceless, unlike the commodities which may be purchased and which have their market value.

Expressing his views on morality and dignity Kant believes that "Now, morality is the condition under which alone an Intelligent can be figured as an end in himself, since by it alone can he become a legislator in the realm of ends. Wherefore morality, and humanity in so far as it is susceptible of that morality, is alone that which has the dignity." (Kant, 1993) According to Kjatran, Kant respect for the personality of each individual. For the mutual respect of the personality, the most important behavior is in accordance with: "...universal laws - that is, rules which, first, restrict every person equally and, second, do not merely represent the choice of one particular person or group" (Kjatran, 2011).

John Stuart Mill advocated individual rights and personal freedoms of human beings and suffrage rights of women. He appreciated the peculiarities of each human being, their uniquenessand originality: "It is not by wearing down into uniformity all that is individual in themselves, but by cultivating it and calling it forth, within the limits imposed by the rights and interests of others, that human beings become a noble and beautiful object of contemplation" (Mill, 2007).

Mill advocated self-development and defence of individuality and autonomy of individuals and the least possible influence of social structures on the opinions and behaviours of individuals. Today this endeavour to limit the social impact on free development of personality, on pursuing personal happiness and guarantees of individual autonomy is recognised as human rights protection, since the basis of inherent dignity of human beings is freedom, which includes physical and spiritual integrity of a person.

Subliming the above understandings of the term dignity, a single position emerges that dignity is a concept applied for highlighting special features of men as noble, elevated and special values, accepted as such in the social system of ethical and moral norms. "The subject of human dignity is the worth of human beings or their high rank, or even their special place in nature" (Kateb, 2011).

\section{Human rights}

Human rights as a legal instrument are based on international and national treaties and pertinent case law. As a moral category, human rights are demands of individuals to be recognised certain rights by the state for the sake of protection of inherent dignity. The notion of human rights was frequently in history the way of pursuing and ending revolutionary demands for respecting human beings and citizens. The essence of human beings has been the 
same at all times. What changed was the relation of the authorities to human beings. Human rights, unalienable from the essence of human beings, exist independently from the will of the ruler. These are the rights "which are not owed to the state or its will, but are possessed by human beings by the mere fact of being a human being, hence independently form any state and without the state" (Dimitrijevich, Paunovich, 1997). These are the rights "which belong to each individual simply by being a human being, independently of any legal texts" (Radonjic, 2004).

The exercise of human rights in a society, their implementation in a legal order of a state means the protection of the inherent human dignity. Inherent dignity of each human being is the source of human rights, since human rights stem from the need to protect human dignity.

Today, legal regulations in contemporary social systems enable the manifestation of fundamental human values, recognition of human rights as the essence of human beings.

\section{An Brief Overview of the History of Human Rights}

Through early history of human society, in the absence of legal regulations, the sense of justice in adjudication is based on moral values and religious commandments. "Religious doctrines are an important substantive source of human rights, they offer common elements from different traditions in the form of universally accepted values as important building blocks for constructing a wider intellectual and cultural concept for the protection of human life, freedom and dignity (Vucinic, 2001)." Justness in court decisions is found and in the Bible: "You shall not do unjustly in judgment. Thou shalt not favor the person of the poor, nor honor the person of the mighty, but thou shalt judge thy neighbor justly (Bible-Old and New Testament, Leviticus) 1968)."

The first formal recognition of certain rights by the rulers, enshrined in legal regulations, emerged in 13c. in England, through the act known as Magna Carta Libertatum (1215), proclaiming that: "No free man shall be seized or imprisoned, or stripped of his rights or possessions, or outlawed or exiled, or deprived of his standing in any way, nor will we proceed with force against him, or send others to do so, except by the lawful judgment of his equals or by the law of the land" (https://www.bl.uk/magna-carta/articles/magna-carta).

The idea of human rights originated from the revolution in the Great Britain in 17c., continued with the revolutions in America and France, then the philosophy of Kant and the political philosophy of John Rolls, as well as Ronald Dworkin's theory of justice in 20c. The French Revolution brought the new political embodiment of the notion of human rights and human dignity in its contemporary meaning. The exercise of rights and freedoms are treated as natural human rights, not as traditional rights. Sovereignty is embedded not in the monarch or the House of Representatives, but in people who are free to change governments and forms of government. In early $18 \mathrm{c}$, the liberal principles of forms of government and the idea of natural rights were presented in the works of Jean-Jacques Rousseau. He supported the true human nature and the natural resistance to inequality and injustice and stood for creating a civil state that would to the greatest extent possible respect the natural human state, considering that the civic form of government gives moral freedom to human beings since "moral liberty, which alone makes him truly master of himself; for the mere impulse of appetite is slavery, while obedience to a law which we prescribe to ourselves is liberty" (Jrousseau, 1993). Such his theories had a substantial impact on shaping the republic as a form of government after the French Bourgeois Revolution, when it became a symbol for the rule of the majority, denying any form of absolute power of the political elite. The American Declaration of Independence from 1776 is not based on traditional rights and privileges, but refers to the rights belonging to all people by nature. According to the Declaration: reads as follows: "We hold these truths to be self-evident, that all men are created equal, that they are endowed by their Creator with certain unalienable Rights, that among these are Life, Liberty and the pursuit of Happiness" (http://www.ushistory.org/declaration/document/). This landmark document paved the way for international protection of human rights, which today constitute one of the most important segments of the international legal order. The law is the expression of the general will. All the citizens, being equal in its eyes, are equally admissible to all public dignities, places and 
employments, according to their capacity and without distinction other than that of their virtues and of their talents.

The theoretical aspects of the development of human rights included several interpretations for the existence of human rights: positivist theories advocated the views of human rights existing based on a high legal act of domestic and international law by which the legislator enables citizens to enjoy human rights. Positivists believe that there is no higher order above or beyond stipulated legal norms created by the authorised legislator. Thus, the positivist Hans Kelsen developed the notion of "positive" law as opposed to the "natural" law (Kelsen, 2003).

John Finnis believes that the issue of morality and human existence does not consist of "making the distinction between the basic aspects of human wellbeing, but in integrating these different aspects in intelligent and reasonable obligations, projects and actions which make one ot the other of many wonderful forms of human life" (Finnis, 2003). According to Dimitrijevich (1997): "This law wich is not positive, is called natural law, and thus, not with standing mutual differences, the theories which believe that in addition to the positive law is some other legal order are called natural law theories - naturalism".

A moderate positivist, Lon L. Fuler, after World War Two, expressed his views of the need to apply the moral dimension in the legal system of states, as well as the need for the legal system to be based on the balance of moral and legal criteria. Discussing legal morality and the notion of positive law and their application in court adjudication, he stated that "law is the enterprise of subjugating human conduct to the reign of rules" (Fuler, 1999), citing Holmes's prediction theory of law: "Prediction what courts will actually do, nothing more pretentious than that, is what I consider law." (Fuler ,1999) According to Fuler, it is obvious that the prediction of court's actions "presume some sort of order" (Fuler,1999), and that it should contain a moral dimension which refers those who pass judicial decisions, in addition to the law, also to the value judgements of the correctness of the ruling made. The application of legal and moral norms in reaching legal decisions, according to them, is the best administration of justice.

The idea of natural rights which claims that, apart from the legal regulations created and sanctioned by the state, there is the order of natural law which emerged before the written law and continues independently of the will of rulers and men is based on the Ancient Greek philosophical ideas of the division of law into the general and particular. The general law exists independently of any written law and is based on the nature of things, and thus has the character of natural law. The natural law theories linked the existence of human rights with human nature and considered human rights to exist regardless of the legislator's will to formulate them in legal acts. John Rolls talked about the equal nature of all human beings and their equal rights to freedom and justice. The principles of justice refer to equal rights of all to freedom and economic equality. Rolls believed that through social contracts a high degree of individual freedom and their better economic position can be achieved. He believed that: "Quite a complex set of rights and duties characterises any particular fundamental freedom, not only should it be allowed to individuals to do or not do something, but the authorities and other individuals must have the duty not to prevent them from doing so." (Rawls, 1998). The exercise of the right to freedom would depend on conditions and circumstances in which these are exercised, and that care should be taken of the ability to "protect the most fundamental interests" (Rawls, 1998).

Ronald Dworkin introduced the terms moral, ethics, and politics in law. Dworkin advocated the theory of natural law by which law exists independently of any state law and should have supremacy in application over the state law. According to Dworkin, human rights exist per se, they do not exist because of the state or of the law, but both the state and the law exist for the sake of human beings and pursuit of human rights. Dworkin believes that the concept of constitutional protection of individual rights is the best protection against the tyranny of majority. This concept brings together the majority and individual rightsof all citizens and is the ideal environment for the protection of human rights and principles for all citizens. Over this period law became not only a public, but also a private matter, thus leading to the expansion of the field of human rights, and by extension, to the limitation of state powers. According to 
Dworkin: "By reference to moral principles, which act a s a limitation of law, rather than by citing the conflicting goals of law" (Dworkin, 2001). According to the doctrine of constitutionalism, which advocates respects for human dignity and human rights: "Human rights are a value per se, ... if such rights and freedoms are to be regulated at all, it can only be the subject matter of the legal act of the highest order (constitution), not the individual acts of the supreme legislature" (Radonjic, 2004).

The intensive evolution of human rights started after World War Two as a response to all atrocities done by human beings to the detriment of other human beings. Finally, the recognition of respect for human rights was given its rightful place in the social structure of the international community. The United Nations were established giving human rights protection the global character. Thus, human rights ceased to be an internal matter of states. The UN Charter, adopted on 26 June 1945 refers to: "Promoting and encouraging respect for human rights and for fundamental freedoms for all without distinction as to race, sex, language, or religion" (Tomovich, Bogićevich, 2003). The UN Charter was the first contractual regulation in international law which established the internationalisation of human rights. Further evolution in international protection of human rights happened with the adoption of the Universal Declaration of Human Rights in 1948, which compiled all previous human rights provisions and gave an impetus for further development of human rights protection. According to Art.1 of the Declaration: "All human beings are born free and equal in dignity and rights. They are endowed with reason and conscience and should act towards one another in a spirit of brotherhood."

Human rights may be seen as inherent, naturally bestowed and unalienable, but also as rights given by states, as a form of limiting the state powers over individuals and guarantee their natural rights: "Subjective rights rest on the norms of objective law, which give and guarantee those rights. Constitution and laws of a state set forth for a very wide range of people, for all citizens of age, some rights, such as the right to contest in elections" (Dimitrijevich, Paunovich 1997).

International instruments implementing the provisions on human rights protection in the legal systems of state parties are particularly important for the respect for human rights. "Social justice refers to the fairness of all social structures, and human rights are implemented in society and their equal and inalienable achievement contributes to social justice and dignified life of an individual in the community" (Ghai, Cottrel, 2011).

By ratifying international treaties, state parties undertake to implement international human rights law and are obliged to align their legal system with the commitments assumed through international treaties. Thus, a single system of international human rights protection is created giving each individual safety and trust in equality and justice in the world. "Justice is essential to our social functioning as is indicated by the fact that the concept of justice (as well as its violation) often dominates our daily experiences and discussions De Cremer, Kees Van den Bos (2007) "Justice and Feelings: Toward a new era in Justice Research", Social Justice Research, 20,1 .

International agreements in the center of their interests put a man and his need to protect his own personality, as a natural and social being. "In discussing the mobilization of international human rights in a specific social and cultural context, one can draw on an ever-expanding socioscientific literature on international rights." (Oomen, 2013) "The rights for others: The Contested Homecoming of Human Rights in the Netherlands", Netherlands Quarterly of Human Rights, 31/1,41-73.)

The recognition of human rights limits the state powers and offers to each individual an equal and just legal protection. Such rights are universal and belong to all people equally, acquired upon birth and exist independently of the will of the state and may not be abolished by the state. Today, human rights are differently recognised and guaranteed to citizens. Developed democracies attach particular attention to human rights protection, unlike the less developed ones, which do not embrace the wide recognition of human rights. 


\section{Research of the human rights committee case law}

State parties to the Optional Protocol to the ICCPR agree that persons under their jurisdiction may address the United Nations Human Rights Committee (HRC) through communications if they believe any of their rights guaranteed by the Covenant has been violated.

An essential issue in all legal structures is to put all the different circumstances and situations that occur in life under the effect of legal norms. Given that life circumstances often go ahead of law, the interpretation of legal provisions is one of the most responsible tasks of those acting upon applications or communications. Researching the given subject in the varied HRC case law I analysed the communications of compatible ratione temporis, ratione materie and ratione personae, in which the HRC established violations of rights guaranteed by the ICCPR invoking the violation of inherent human dignity in their statements of reasons. The HRC is the only: "Universal body dealing with individual issues of human rights violations in facing the situations that no one could have envisaged and which only life can bring about in all its complexity, fullness and uniqueness. The HRC must apply creatively the ICCPR provisions, interpreting it in the global sense, i.e. taking care that the standards it takes into account should not be particular or linked with a specific ideology of understanding life" (Dimitrijevich, 1989) "Komitet za ljudska prava" (The Human Rights Committee).

Once the HRC has established violation of rights guaranteed by the ICCPR, it requires from the state party, concerned to provide adequate remedy to the author of the communication, proper compensation and other necessary measures to prevent further similar violations. When considering the reports by state parties, the HRC adopts general comments noting deficiencies or difficulties in respecting and implementing the ICCPR provisions and issues recommendations in which: "The HRC in a general form indicates the shortcomings and deficiencies in those reports and takes a position on those ICCPR provisions which are differently interpreted in such country reports" (Dimitrijevich (1989) "Delatnosti Komiteta za ljudska prava" (Activities of the Human Rights Committee) which, through their moral authority, affect more consistent implementation of the ICCPR provisions by state parties and ensure enjoyment of human rights thus guaranteed because the HRC, where the representatives of different civilisations, schools of legal thought and ideologies sit, adopts them by consensus.

The aim of adopting general comments of HRC is to make the experiences of treaty bodies available to state parties and to serve as guidance for further improvement of the state of human rights in the country. "Committees help state parties to overcome the difficulties occurring in implementing international treaties, in addition to interpreting some specific rights guaranteed by international treaties, by giving guidance in general comments for further enhancement of human rights, proposing measures to be undertaken and improvements to be made" (Dimitrijevich et al., 2007).

The HRC establishes whether the state party concerned violated any of the rights guaranteed by the ICCPR against the author of the communication and publishes its decision in its periodic reports (Reports of the Human Rights Committee:

(http://www.ohchr.org/EN/HRBodies/CCPR/Pages/CCPRIndex.aspx).

Studying the HRC practice in implementing the provisions of the ICCPR, I singled out those communications where the HRC established that due to the violation of human dignity some of the rights guaranteed by the ICCPR were violated. The applications lodged are stated in the chronological order, together with the relevant Convention articles and HRC reports upon considering the communications:

1. Comm., No. 481/1991, Jorge Villacanes v. Ecuador, art. 7 i 10 par. 1, 14 par. 3(c), $\mathrm{A} / 52 / 40$.

2. Comm.No. 523/1992, Clyde v. Trinidad and Tobago, art. 9 par. 3 and 14 par. 3(c), $\mathrm{A} / 51 / 40$.

3. Comm., No. 512/1992, Daniel Pinto v. Trinidad and Tobago, art. 7 and 10 par. 1, $\mathrm{A} / 51 / 40$. 
4. Comm., No.571/1994, Eustance Henry and Everald Douglas v. Jamaica, art. 7 and 9 par.3,10 par.1,14par.3(c), A/51/40.

5. Comm., No. 707/1996, Patrick Taylor v. Jamaica, art.9 par. 2 i 3,10 par. 1, art. 14 par.1and14 par.3(c), and 6, A/51/40.

6. Comm., No.695/1996, Simpson v. Jamaica, art. 2, 10 par. 1 and art. 14 par. 3 (d), $\mathrm{A} / 57 / 40$.

7. Comm., No. 683/1996, Wanza v. Trinidad and Tobago, art. 10 par. 1, art.14 par. 3(c), $\mathrm{A} / 57 / 40$.

8. Comm., No. 721/1997, Boodo v. Trinidad and Tobago, art. 7 i 9 par. 3, 10 par. 1, 14 par. 3(c), 17 and 18, A/57/40.

9. Comm., No 793/1998, Pryse v. Jamaica, art. 7 and 10, par. 1, A/59/40.

10. Comm., No. 798/1998, Howelly v. Jamaica, art. 7 and 10 par. 1, A/59/40.

11. Comm., No. 868/1999, Wilson v. Jamaica, art. 7, 9 par, 1, 2 i 3, art. 10 par. 1 i 2, $\mathrm{A} / 59 / 40$.

12. Comm., No. 899/1999, Francis et. al. v. Trinidad and Tobago, art. 9 par. 3, 10 par. 1, 14 par. 3(c), A/57/40.

13. Comm., No. 927/2000, Svetlik v. Belorus, art. 19 par. 2 and 3, A/59/40.

14. Comm., No. 931/2000, Hodoyberganova v. Uzbekistan, art. 14, A/59/40.

15. Comm., No.938/2000, GirjadatSiwpersud et al. v. Trinidad and Tobago, art. 9 par. 3, 10 par. 1 and art. 14 par. 5 in 3(c).A/59/40.

16. Comm., No.1033/2001, Nallaratnam v. Sri Lanka, art. 5 and 14, par .5, A/59/40.

17. Comm., No.992/2001, Bousround v. Algeria, art. 7 and art. 9 par. 1, 3, 4 and 10, $\mathrm{A} / 61 / 40$.

18. Comm., No.1050/2002, D. and E. v. Australia, art. 9 par. 1 and 2, 19, 12 par. 1, $\mathrm{A} / 61 / 40$.

19. Comm., No.1069/2002, Bakhtairi v. Australia, art. 9 par. 1 and 4 and art. 24 par. 1, $\mathrm{A} / 59 / 40$.

20. Comm., No.1167/2003, RamilRayos v. The Philippines, art. 6, par. 1, and art. 14, par. 3 (b), A/59/40.

21. Comm., No.1128/2002, Marques v. Angola, art. 9 par. 1 and 2, 19, 12 par. 1, A/60/40.

22. Comm., No.1126/2002, Carranza v. Peru, art. 9, 7, 10 and 14, A/61/40.

23. Comm., No.1196/2003, Boucherf v. Algeria, art. 2 par. 3, 7, 8 and 9, 16. A/61/40.

24. 24.Comm., No.1232/2003, Pustovalov v. Russian Federation, art. 7and art. 14 par. 3 (b, d and e), A/65/40.

25. Comm., No.1439/2005, Aber v. Algeria, art. 7 and 9 par 3, 10 par. 1, A/62/40.

26. Comm., No.1327/2004, Grioua v. Algeria, art. 2 par. 3, 7, 8, 9, 16, A/62/40.

27. Comm., No.1328/2004, Kimouche v. Algeria, art. 2 par. 3, 7, 8, 9, 16, A/62/40.

28. Comm., No.1373/2005, Dissanakye v. Sri Lanka, art. 9 par. 1, 19, 25 (b),A/63/40.

29. Comm.,No.1422/2005, El Hassy v. The Libyan Arab Jamahiriya, art. 5, 7, 9, 10, $\mathrm{A} / 63 / 40$.

30. Comm., No. 1406/2005, Weerawansa v. Sri Lanka, art. 9 par. 1, art. 19, art. 25 (b), $\mathrm{A} / 64 / 40$.

31. Comm., No.1369/2005, Kulov v. Kirgistan, art. 7, 9 par.1, 3, 4, art. 14 par. 1, 2, 3 (b), (c), (d) and(e), A/65/40.

32. Comm., No.1442/2005, Kvokv. Australija, art. 9, A/65/40.

33. Comm., No.1402/2005, Tatiana Krasnova v. Kirgistan, art.7, 9 par.2 i art. 14 par. 1, 3 (b), and 3(c), A/66/40.

34. Comm., No.1410/2005, Ievdokimov and Rezanov v. Russian Federation, art. 2, par. 1 and $3,25, \mathrm{~A} / 66 / 40$.

35. Comm., No.1412/2005, Butovenko v. Ukraine, art. 7, 9 par. 1, art. 10 par. 2 and 14 par. $1,3(\mathrm{~b}),(\mathrm{d}),(\mathrm{e})$ and $(\mathrm{g}), \mathrm{A} / 66 / 40$.

36. Comm., No.1449/2006, Umarov v. Uzbekistan, art.7,9 par. 1,3,4, 10 par. 1 and 19 par. $2,26, \mathrm{~A} / 66 / 40$. 
37. Comm., No.1450/2006, Komorovski v. Turkmenistan, art. 9 par. 1, 19, 25 (b), A/63/40.

38. Comm., No. 1520/2006, Mvamba v. Zambia, art. 6, 7, 10 par.1, 14 par. 2 and 3 (c) and $5, \mathrm{~A} / 65 / 40$.

39. Comm., No 1588/2007, Benzaiza v. Algeria, art.7, 9, 16, 2, 6 par. 1, A/65/40.

40. Comm., No 1640/2007, El Abani v. Libia, art. 2 par. 3, 6 par. 1, 16, A/65/40.

41. Comm., No 1870/2009, Sobhraj v. Nepal, art. 10 par. 1, 14 par. 1, 2, 3, 5 i 7, A/65/40.

42. Comm., No. 1759/2008, Traore v. Cote d'Ivoire, art. 2 par. 3; 6, par. 1; 9; and 10, par. $1, \mathrm{~A} / 67 / 40$.

43. Comm., No. 1781/2008, Bergizv.Algeria, art. 2 par. 3; 6, par. 1; 7, 9 (1-4); and 10, par. $1,16, \mathrm{~A} / 67 / 40$.

44. Comm., No. 1782/2008, Aboufaied v.Libya, art. 2 par. 3; 6, par.1; 7,9 (1-4); and 10, par. 1, 12 par. 2, 14, 16, 19, 21. A/67/40.

45. Comm., No.1811/2008, Djebar and Chihoub v.Algeria, art. 2, par. 3, t. 6, par. 1, 7. 9 par.1 to 4, 10 par. 1, 16, 17, 23 par. 1, 24, A/67/40.

46. Comm., No. 1834/2009, A.P. v. Ukraine, art. 2 par. 1 and 3(a) and (c), art. 4 par. 2; 7; 9; par. 1 and 3; art. 14 par. 1, 3 (b) (d) and (e) and 7; 19. par. 2, A/68/40.

47. Comm., No. 1858/2009, Y.M. v. Russian Federation, art. 2, par. 3, 7, 9 par. 1, 3 and 5, 10 par. 1, 14, par.1, 16 and 26, A/67/40.

48. Comm., No. 1962/2010, S.N.A. v. Cameron, art. 1, 7, 9, 10, 17 and 19, A/68/40.

49. (Reports on Human Rights Committee: http://www.ohchr.org/EN/HRBodies/CCPR/Pages/ CCPRIndex.aspx).

The research is completed with the review of the Report on Human Rights Committee: A/71/40 (31 ${ }^{\text {st }}$ March 2017).

\section{Results and discussion}

1. By examining and analysing the $48 \mathrm{HRC}$ decisions stated above, where the HRC established the infringement of human rights due to the violation of inherent human dignity, I established that the violation of human dignity in the largest number of cases referred to the following ICCPR provisions: Art. 7 in 25 cases (52.08\%); Art. 10 para. 1 in 22 cases (45.83\%); art. 9 para. 1 in 18 cases (37.5\%); Art. 9 para. 3 in 16 cases (33.33\%); Art. 14 para. 3(c) in 12 cases $(25 \%)$; Art. 9 para. 2 in 8 cases $(16.66 \%)$; Art. 14 para. 1 in7cases (14.58\%); Art. 19 in.8cases (16.66\%); Art. 9 in5cases (10.41\%); Art. 16 in7cases (14.58\%); Art. 9 para. 4 in 5 cases $(10.42 \%)$; Art. 14 para. 2 in 4 cases $(8.33 \%)$; Art. 2 para. 3 in 9 cases (18.75\%); Art. 14 in 6 cases (12.5\%); Art. 10 in 4cases (8.33\%); Art. 14 para. 5 in 3 cases (6.25\%); Art. 2 para. 7 in 3 cases (6.25\%); Art. 2 para. 8 in 3 cases (6.25\%); Art. 2 para. 9 in 3 cases (6.25\%); Art. 12 para. 1 in 3 cases (6.25\%); Art. 25 para. (b) in 3 cases (6.25\%); Art. 19 para. 2 in 2 cases (4.16\%); Art. 5 in 2 cases (4.16\%); Art .6 in5cases (10.41\%); Art. 26 in 2 cases (4.16\%); Art 25 para. b in 3 cases (6.25\%); Art. 24 in 2 cases (4.16\%); Art. 19 para. 3 in 1 case (2.08\%); Art. 14 para. 3 (b) in 2 cases, (4.16\%); Art. 14(c) in 1 case (2.08\%); Art. 25 in 1 case (2.08\%); and Art. 14(e) in 2 cases $(4.16 \%)$.

2. The results of researching shows the largest number of cases establishing violation of human dignity (52.08\%) refer to ICCPR, Art. 7 which reads: "No one shall be subjected to torture or to cruel, inhuman or degrading treatment or punishment. In particular, no one shall be subjected without his free consent to medical or scientific experimentation".

Under item 2 of the General Comment no.20: "The aim of the provisions of article 7 of the International Covenant on Civil and Political Rights is to protect both the dignity and the physical and mental integrity of the individual" (UN Human Rights Committee, General Comment no. 20: Article 7 (Prohibition of Torture, or Other Cruel, Inhuman or Degrading Treatment or Punishment; http://www.refworld.org/docid/). General Comment no. 20 further states: "The prohibition in article 7 is complemented by the positive requirements of article 10 , paragraph 1, of the Covenant, which stipulates that "All persons deprived of their liberty shall 
be treated with humanity and with respect for the inherent dignity of the human person (CCPR, General Comment no. 20: http://www.refworld.org/docid/).

3. During the analysis, I singled out the reasons which made the HRC invoke the violation of human dignity in reference to the infringements of Art. 7 of the ICCPR, and these include: physical assaults, torture, cruel treatment, intimidation, administering unidentified substances, the cases where medical condition exacerbated during incarceration, enforced disappearance, failure to report incarceration or detention, when inflicting pain, stress, suffering, being forced to stay in unlit, small, over-crowded prison cells, prohibition to take medication, maltreatment to coerce to admission of guilt, being detained incommunicado (prolonged prohibition of visitations, correspondence).

4. Art. 10 para 1 was violated in $40 \%$ the cases where the HRC established infringement on the account of violation of human dignity: horrible prison conditions (small and crowded cells, no light, no beds), physical punishment and torture, failure to provide medical assistance and treatment, enforced disappearance, being shackled while incarcerated with no food and water, etc.) since these actions violate inherent human dignity protected by Art. 10 of the International Covenant on Civil and Political Rights, which reads: "All persons deprived of their liberty shall be treated with humanity and with respect for the inherent dignity of the human person (U.N.T.S., 1976: no. 14668, vol. 999, p. 171)."

In actions taken by states against their own citizens, apart from most common violations of Art. 7 and Art. 10 para. 1, another quite common violation is that of Art. 9 para. 1(11\%) and para. $3(11 \%)$, which refers to liberty and security of person and reads as follows: "Everyone has the right to liberty and security of person. No one shall be subjected to arbitrary arrest or detention. No one shall be deprived of his liberty except on such grounds and in accordance with such procedure as are established by law (U.N.T.S., 1976: no. 14668, vol. 999, p. 171)".

In its General Comments, (UN Human Rights Committee (HRC), General comment no. 35, Article 9 (Liberty and security of person), http://www.refworld.org/docid/), the HRC considers liberty of person to be the right of profound importance. The ICCPR Art. 9 recognises and protects liberty and security of person. Liberty of person in terms of this provision refers to freedom from physical incarceration, not the general liberty of actions, and security refers to being free form bodily injuries and preservation of physical integrity and the right to personal security, independent of the right to liberty of person. Art. 9 guarantees this right to everyone: "Everyone" includes, among others, girls and boys, soldiers, persons with disabilities, lesbian, gay, bisexual and transgender persons, aliens, refugees and asylum seekers, stateless persons, migrant workers, persons convicted of crime, and persons who have engaged in terrorist activity.

5. Further, by examining the HRC case law, I established that the Committee in its decisions interprets the term dignity in different ways, conceptualising its meaning according to the facts and circumstances of each individual case. As particularly aggravating, the HRC took to be the circumstances involving a person never brought before the court or if that has not been done within the statutory deadlines, then the disappearance of a person in prison, prolonged incommunicado, limitation of the rights to habeas corpus, unnecessary delays of trial, the period of three years before pre-trial detention and trial, imposing detention without being heard before competent persons, denying the right to an attorney throughout the proceedings, arbitrary arrest or prolonged solitary confinement (12 years). The HRC individualises the criteria for establishing violations of the rights guaranteed by the ICCPR, particularly taking care of mental, physical and health status of the person, of the applied measures of repression, duress, fear, threat or coercion to specific acts that undermine the dignity of each individual, and how the facts and circumstances that the applicant alleges are reflected on the violation of their inherent dignity.

6. Given the number of applications lodged with the HRC from around the world, by interpreting and conceptualising the notion of dignity and through individualisation of specific circumstances of each individual case, the structure of existing human rights norms is expanding and current national and international legal system further developed. Thus, the 
protection of dignity as an inherent human value, and the source of human rights, is becoming a common standard and the basis for further development of national and international legal regulation.

A particular challenge for all interpreters of legal norms is how to put new and different circumstances and situations under the impact of legal regulation. Therefore, holders of social authorities that interpret legal regulations and apply them to specific situations, have the very important task to extend the effect of the legal norm through their interpretation, thus creating new aspects and levels of human rights protection which protect human dignityin the best way possible, building specific systems of values for respecting human beings in all life circumstances. Thus, through its case law, the HRC helps the alignment of state parties'legal regulations with the international one and creates a common basis for ever more effective human rights protection. Under Art. 4 para. 2 state parties are obliged to: "Within six months, the receiving State shall submit to the Committee written explanations or statements clarifying the matter and the remedy, if any, that may have been taken by that State (Optional Protocol to the International Covenant on Civil and Political Rights http://www.ohchr.org/EN/ProfessionalInterest//OPCCPR1).

When to confirm once the violation of any of the rights guaranteed by the ICCPR is established, State party is given recommendations which, in addition to the compensation for the author of the communication, also impose obligations for the State party to have legislative changes, which may refer to laws and other legislation, and to align them with international regulations. The HRC with its recommendations, for instance in reference to Art 7 and 9 of the ICCPR, instructs the state concerned, that violated any of the rights guaranteed by the ICCPR, to ensure in its legislation, instead of detention and incarceration, other measures of enforcement (bail, mandatory reporting to relevant institutions and electronic bracelets).

In reference to Art. 9, the HRC constantly demands relevant states to respect the right to fair trial (inform the persons of the reasons of arrest, mandatory interrogation, presence of an attorney throughout the proceedings, reasonable times for pre-trial detention and other measures in reference to specific cases).

7. The HRC recommendations have particular significance for the population of underdeveloped democracies, since the improvement of the respect for each individual by implementing the new legal instruments develops the rule of law domestically.

As final considerations, in addition to the above, I would like to point to the sociological importance of General Recommendations and HRC recommendations which assist state parties to establish the practice of reaching decisions in specific cases by indicating the elements of legal and social culture in need of improvement, thus complementing the protection of human rights of persons under their jurisdiction. The sociological aspect of human rights protection is seen primarily in the respect for human beings in all life circumstances and in all societal structures and encouraging state parties with relevant legal instruments to improve the legislation and social status of their populations.

The specific significance of the HRC case law and its recommendations is seen in the individualisation and conceptualisation of the notion of dignity thus extending the effect of the legal norm and creating new levels of protection for human dignity by individualising specific circumstances.

\section{Conclusion}

In the introduction I cited the examination of the influence of the HCR recommendations in the implementation of the ICCPR as one of the motifs for the paper. The paper links the historic development of human rights and the contemporary human rights protection through the HRC decision, particularly focusing on the protection of dignityas the ethical value and the source of human rights. Natural features of an individual are the same in all times, but their manifestation and recognition has come a long waythrough social evolution positioning human dignity as an aim aspired to in the functioning of the global human rights protection system. I particularly 
highlighted the HRC recommendations that invoke the protection of human dignity in their statements of reasons when establishing a violation of a certain human right and by analysing their contents I found the areas guaranteed by the ICCPRwhich are most prone to violation of human dignity. Analysing the HRC case law, one becomes aware of the evolving humanisation of access to protection of human dignity. Assessing individual facts and circumstances of each case, and by conceptualising dignity, the HRC creates new aspects and levels of human rights protection and protects human dignity in the most objective way. Ratifying human rights treaties, modern states express their readiness to guarantee to the citizens under their jurisdiction the recognition of rights guaranteed by international instruments. By cherishing the value of respect for human beings in all living circumstances, the HRC effectuates the humanisation of legal orders of state parties in the sense of having just evaluation of protection for human dignity and just balance between applying the legal regulation and moral values.

\section{REFERENCES}

1. Aquinas, T. (2003) On Being and Essence, Dereta, Belgrade.

2. American declaration of independes (http://www.ushistory.org/declaration/document/).

3. Bible-Old and New Testament, Leviticus, (1968), Stvarnost, Zagreb.

4. Bingham, T. (2011) The Rule of Law, Penguin books, London.

5. Charter of the United Nations (https://www.un.org/en/charter-united-nations/).

6. De Cremer D. and Kees van den Bos (2007) "Justice and Feelings: Toward a new era in Justice Research", Social Justice Research, Vol. 20, 1, 1-9, p.1.

7. Dimitrijevich, V.and Paunovich, M. (1997) Human Rights, Center for Human Rights, Belgrade.

8. Dimitrijevich, V. (1989) "Komitet za ljudska prava" (The Human Rights Committee), Jugoslovenska revija za međunarodno pravo, vol. 1-2, p. 73.

9. Dimitrijevich, V. (1989) "Delatnosti Komiteta za ljudska prava" (Activities of the Human Rights Committee)., Jugoslovenska revija za kriminlogiju i krivičnopravo, vol. 27, 1, p. 5.

10. Dimitrijevich, V. Popovich, D. Papich, T. Petrovich, V. (2007) Međunarodno pravo ljudskih prava (International Human Rights Law), Dosije, Belgrade.

11. Dworkin, R. (2001Taking Rights Seriously, Institut za otvoreno društvo Crne Gore, CID, Podgorica.

12. Finnis, J. (2003) The Natural Law and Natural Rights, CID, Podgorica.

13. Ghai Y. and Cottrel, J. (2011) The Millenum Declaration, Rights, and Constitutions, Oxford University Press, Oxford.

14. Hobbes, T. (2004) Leviathan, Jesenkii Turk Hughes, Zagreb.

15. International Covenant on Civil and Political Rights (ICCPR). United Nations Treaty Series (1976), 999, I-14668,171. Aviable at: hhtps://treaties.un.org/volume 999/I-14668.

16. Kateb, G. (2011) Human Dignity, Harvard University Press, Cambridge, Massachusetts and London.

17. Kjatran Koch Mikalsen (2011) "Indeference of Kant s League of states", Law and Philosophy, vol. 30, 291-317.

18. Heraclitus, (2006) On the nature, Oktoih, Podgorica.

19. Kant, I. (1993) The Metaphysics of Etics, Izdavačka knjižarnica Zorana Stojanovića, Novi Sad.

20. Kelzen, Hans (2003) The problem of sovereignty and the theory of international law, Službeni list Srbije i Crne Gore, Beograd.

21. Lutz, A. Mark (1995) "Centering Social Economics on Human dignity". Review of Social Economy, vol. 53, 2, pp. 171-194.

22. Magna Carta Libertatum (https://www.bl.uk/magna-carta/articles/magna-carta).

23. Mill J.S. (2007) On Liberty, Center for the Publications of the Law Faculty, University of Belgrade, Belgrade.

24. Oomen, B. (2013) The rights for others: The Contested Homecoming of Human Rights in the Netherlands, Netherlands Quarterly of Human Rights, Vol. 31/1, 41-73, p. 52.

25. Optional Protocol to the International Covenant on Civil and Political Rights, available at: www.ohchr.org/OPCCPR1.

26. Radonjich, R. (2004) Demokracy, CID, Podgorica.

27. Rawls, J. (1998) The Theory of Justice, Službeni list Srbije i Crne Gore, Podgorica, Beograd.

28. Rousseau, J.J. (1993) Social Contract, Filip Višnjić, Beograd. 
29. Tomovich, Z. and Bogichevich, C. (2003) Human rights - international documents, Oktoih, Podgorica.

30. UN Human Rights Committee (HRC), CCPR General Comment No. 20: Article 7 (Prohibition of Torture, or Other Cruel, Inhuman or Degrading Treatment or Punishment), 10 March 1992, available at: http://www.refworld.org/docid/.

31. UN Human Rights Committee (HRC), General comment no. 35, Article 9 (Liberty and security of person), 16 December 2014, CCPR/C/GC/35, available at: http://www.refworld.org/.

32. Universal declaration of Human Rights, adopted 10 Decembar 1948 UNGA Res 217 A(III) (UDHR) art. 1. (https: www.un/org/en/universal-declaration-human - rights)

33. Vucinić, N. (2001) Fundamentals of human rights and freedoms), CID, Podgorica. 